\title{
Comparison of Viral Clearance between Ivermectin with Doxycycline and Hydroxychloroquine with Azithromycin in COVID-19 Patients
}

\author{
MA RAHMAN ${ }^{\mathrm{a}}, \mathrm{SA} \mathrm{IQBAL}^{\mathrm{b}}$, MA ISLAM$^{\mathrm{c}}$, MK NIAZ $^{\mathrm{d}}, \mathrm{T} \mathrm{HUSSAIN}^{\mathrm{e}}$, TH SIDDIQUEE $^{\mathrm{f}}$
}

\begin{abstract}
:
Introduction: The whole world is on the brink of collapse due to the outbreak of COVID-19 with no solution to treat these cases with any specific drug. Extensive search for the Vaccine or effective treatment is going on while alarming infection and death toll is rising every day.
\end{abstract}

Aim: The study will compare the effect of Ivermectin with Doxycycline and Hydoxychloroquine with Azythromicin on a selective group of COVID -19 positive patients.

Method: This is a comparative study that included 400 patients of COVID 19 positive patient who were divided in to two groups. Group-A Received Ivermectin with Doxycycline and the other group- B received hydroxichloroquine(HCQ) with azithromycin.

Result: Viral clearance is 132 ( 66\%) on day 5 and 167( $83.5 \%$ ) on day 6. Among them 33(16.5\%) remain PCR positive after 6th day of Ivermectin ingestion in Group $A$. Whereas there is 154 (77.0\%) viral clearance at 11th day and

Introduction:

While the world is awaiting a vaccine, the death toll is rising day by day. We need to find effective drugs to treat coronavirus disease-19 (COVID-19). Several drugs have been proposed and practiced worldwide but none is confirmed or approved. In this study we are looking for an answer for the large group of population of this poor country.

a. Md Azizur Rahman, Adv Spl in Medicine \& Pulmonology, Brigadier General

b. Syed Asif Iqbal, Chief Physician General, Brigadier General

c. Md Azizul Islam, Consultant Physician General, Major General

d. MD. Kaisar Niaz Classified Specialist Medicine, Major

e. Tahmeed Hussain Classified Specialist Medicine, Major.

f. Taufiqul Hasan Siddiquee, Commandant $\mathrm{CMH}$, Brigadier General

Address of the Correspondence: Brigadier General Md Azizur Rahman, Adviser Specialist in Medicine \& Pulmonology, CMH, Dhaka. E-mail: majazizur765@yahoo.com
163(81.5\%) viral clearance at 12th day of Hydroxychloroquine ingestion in Group B. Among them 37 (18.5\%) remain PCR positive after 12 day in group $B$. The P value is 0.000427 which is significant considering 5th day viral clearance of Ivermectin ingestion and 11th day of Hydroxychloroquine ingestion. But considering 6th day and 12th day the P-value is 0.59 which is not significant.

Conclusion: It appears Ivermectin and Doxycycline is safeand effective combination drug therapy in COVID19 infected patients but need further extensive study to find out the scope of application on other groups of patients.

Keywords: COVID-19, Ivermectin, Hydroxychloroquine, Doxycycline, Doxycycline Azithromycin Hydroxychloroquine with Azithromycin

(J Bangladesh Coll Phys Surg 2020; 38: 5-9) DOI: https://doi.org/10.3329/jbcps.v38i0. 47514

A novel coronavirus 2019-nCoV was first identified in the state of Wuhan, China, at the end of 2019. Coronaviruses are basically a group of viruses containing nonsegmented, single-stranded RNA. These groups of virusescaused several outbreaks around the world, like 'Severe Acute Respiratory Syndrome (SARS) pandemic' in 2002-2003 and the 'Middle East Respiratory Syndrome (MERS) outbreak' in South Korea in 2015. But most recently,COVID-19 triggered an outbreak in China in December 2019, subsequently become pandemic. Though some of corona patient reached in to devastating epidemics outcome, but others manifested mild to moderate respiratory infections, like the common cold. ${ }^{1}$

Ivermectin is a broad spectrum anti-parasiticagent ${ }^{2}$ seems to have some anti-viral activities against a large number of viruses $3,4,5,6$ in vitro. Originally identiûed as an inhibitor of inter action between the human immunodeûciency virus-1(HIV-1) integrase protein (IN) and the importin (IMP) á/âl heterodimer responsible for IN nuclear import. ${ }^{7}$ Studies on SARS-CoV proteins have 
revealed a potential role for IMPá/âl during infection in signal dependent nucleocytoplasmic shutting of the SARS-CoVnucleo capsid protein, ${ }^{8,9,10}$ that may impact host cell division, ${ }^{11,12}$ addition of the SARS-CoV accessory protein ORF6 has been shown to antagonize the antiviral activity of the STAT1 transcription factor by sequestering IMPá/â1 on therough ER/ Golgi membrane13. Taken together, these reports suggested that Ivermectin's nuclear transport inhibitory activity may be eûective against SARS-CoV-2. When doxycycline was combined with macrocyclic lactonesin adult worms, ivermectin efficacy was $80 \%$ compared with $9 \%$ when treatment was performed with doxycycline alone 14 The largest dose intensity with registered pharmacokinetic parameters in healthy subjects is 120 $\mathrm{mg}$, corresponding to up to $2000 \mu \mathrm{g} / \mathrm{kg}$. ${ }^{15}$

HCQ has shown antiviral effects at both preinfection and postinfection stages. HCQ could interfere with the glycosylation of angiotensin-converting enzyme 2, thereby reducing the binding efficiency between angiotensin-converting enzyme 2 on host cells and the SARS-CoV-2 spike protein. Moreover, HCQ could be able to block virus fusion with the host cell through the inhibition of protease activity in cleaving corona virus surface spike proteins. ${ }^{16}$

Far less is known about the antiviral effects of azythromicin, which has been suggested to interfere with influenza virus internalization ${ }^{17}$. Interestingly, CLQ is also considered as an inhibitor of endocytic pathways through an elevation of endosomal $\mathrm{pH}^{18}$. azithromycin was added to hydroxychloroquine, the efficiency of SARS CoV-2 elimination was significantly improved. ${ }^{19}$

Regarding diagnosis till now no test is gold standard making it more challenging in diagnosing the disease.Specificity of RT-PCR is dependent on site, like $63 \%$ for nasal swabs, and only $32 \%$ for throat/ pharyngeal swabs. ${ }^{20}$

\section{Method:}

It's a prospective comparative studyconducted at Combined Military Hospital Dhaka. Total 400 Covid-19 PCR positive patients were included in this study. Among them 200 cases received ivermectin $18 \mathrm{mg}$ on first day and Doxycycline $100 \mathrm{mg}$ twice daily for 05 days comprising Group A and the rest 200 patients were given hydroxichloroquine $800 \mathrm{mg}$ on first day then $400 \mathrm{mg}$ daily for 10 days and azithromycin $500 \mathrm{mg}$ one day then $250 \mathrm{~g}$ daily for 4 days comprised Group B.Diagnosis of Covid19 was done by RT-PCR from nasal and pharyngeal swab. The patients who had mild to moderate disease according to 'National Guideline on clinical management of coronavirus disease 2019 (COVID-19) version 7.0' were included in this study. Severe and critical patients were excluded from the study.Patientswere admitted in corona ward in April 2020 were given RT- PCR on 11th day and 12th day in Group B after completion of the recommended dose. Whereas the PCR test were done on 5th and 6th day after ingestion of Ivermectin in corona ward during May 2020 in Group A. The date of check Rt-PCR was determined by the recommended dose of different drugs used in this study.

\section{Result:}

Total 400 patients were included in this study. None developed severe or critical disease during study.

\section{Table-I}

Demographic profile $(n=400)$

\begin{tabular}{lcc} 
Demographic profile & Group A & Group B \\
\hline Mean age in years & 36.4 & 39.42 \\
Age range in years & $17-74$ & $20-79$ \\
Male & $78.5 \%(157)$ & $188(94 \%)$ \\
Female & $21.5 \%(43)$ & $12(6 \%)$ \\
\hline
\end{tabular}

Above table shows demographic profile in which $78.5 \%$ (157) were male; $21.5 \%$ (43) were Female in Group A and $188(94 \%)$ male and $12(6 \%)$ female in group B. Their age range was 17-74 with mean 36.46 years in group $A$ and in group B age range 20-79 with mean 39.42 years.

Symptoms of the patients during admission $(n=400)$

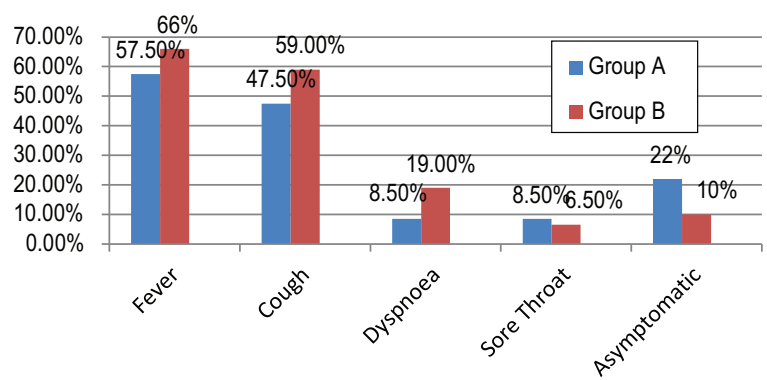

Fig.-1: Showing Symptoms of Patient during admission 
It shows that maximum patient had fever $57.5 \%$ and $66 \%$ in group A and B. Then next common symptom was Cough $47.5 \%$ and $59 \%$. There were $22 \%$ patient who had no Covid symptoms in group A and only $10 \%$ in group $B$

Co-Morbidities of the patients $(n=400)$

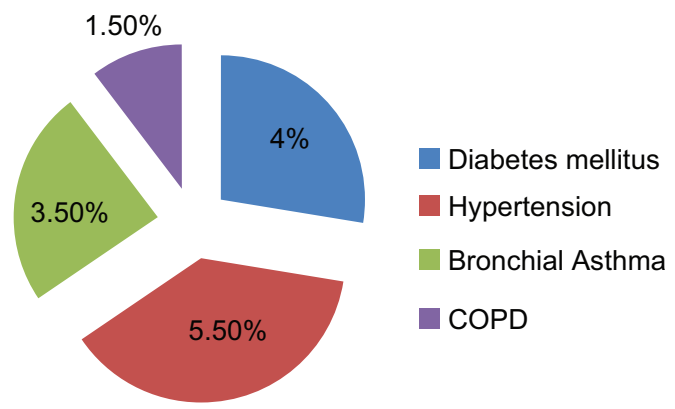

Fig.-2: Pie chart Showing Co-morbidities of Group A

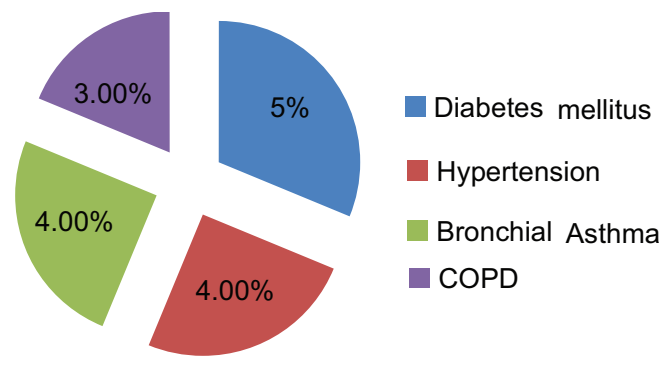

Fig.-3. Pie chart showing Co- morbidities of GroupB

Among the patients $11(5.5 \%)$ had hypertension in group A and $8(4 \%)$ in Group B, 8(4\%) and 10 ( 5\%) had diabetes mellitus respectively, $7(3.5 \%)$ and $8(4 \%)$ had Bronchial Asthma and 3 (1.50\%) and 6 (3\%) had COPD.

Viral Clearance of Group A and B $(n=400)$

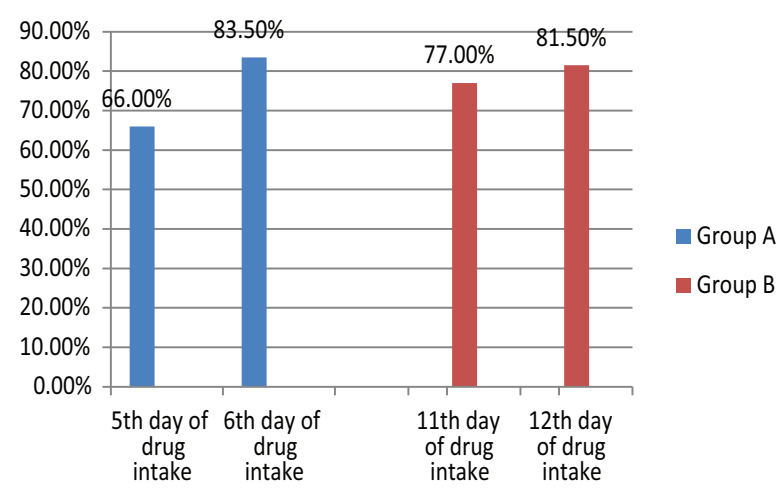

Fig.-4: showing Viral Clearance
Diagram showing viral clearance is $132(66 \%)$ on day 5 and $167(83.5 \%)$ on day 6 . Among them $33(16.5 \%)$ remain PCR positive after 6 th day of ivermectin ingestion in Group A. Whereas there is 154 (77.0\%) viral clearance at 11 th day and $163(81.5 \%)$ viral clearance at 12 th day of hydroxychloroquine ingestion in Group B. Among them $37(18.5 \%)$ remain PCR positive after 12 day in group B. The $\mathrm{P}$ value is 0.000427 which is significant considering 5 th day viral clearance of ivermectin ingestion and 11 th day of hydroxychloroquine ingestion. But considering 6th day and 12 th day the P-value is 0.59 which is not significant.

Table-II

Uncommon Symptoms in Group A and B

\begin{tabular}{lccc}
\multicolumn{2}{c}{ Group A $(\mathrm{n}=200)$} & \multicolumn{2}{c}{ Group B $(\mathrm{n}=200)$} \\
\hline Symptoms & $\mathrm{n}(\%)$ & Symptoms & $\mathrm{n}(\%)$ \\
Anorexia & $47(23.5)$ & Anorexia & $62(31)$ \\
Vomiting & $7(3.5)$ & Vomiting & $4(2)$ \\
Diarrhoea & $24(12)$ & Diarrhoea & $14(7)$ \\
Skin Rash & $20(10)$ & Skin Rash & $2(01)$ \\
\hline
\end{tabular}

Above table shows some uncommon symptoms of the disease which can also be considered as drug effect due to sharing of the nature of presentation where anorexia $(23.5 \%$ and $31 \%)$ is the predominant feature is also a documented symptoms of Covid. Next effect was diarrhea (12\%) in group A. Others were skin rash (10\% and $1 \%)$ and vomiting (3.5\% and $2 \%)$.

Table-III

\begin{tabular}{lcc}
\multicolumn{3}{c}{ Liver and Renal biochemical changes after drug } \\
intake in Group $A$ and $B$ \\
Group A & \multicolumn{2}{c}{ Group B } \\
Parameter & Mean & Mean \\
Serum Bilirubin & $0.55 \pm 0.19 \mathrm{mg} / \mathrm{dl}$ & $0.58 \pm 0.07 \mathrm{mg} / \mathrm{dl}$ \\
ALT & $34.16 \pm 21.7 \mathrm{IU} / 1$ & $29.16 \pm 18.8 \mathrm{IU} / 1$ \\
ALP & $79.95 \pm 28.56 \mathrm{IU} / 1$ & $88.6 \pm 23.77 \mathrm{IU} / 1$ \\
GGT & $51.23 \pm 56.18 \mathrm{IU} / 1$ & $49.23 \pm 66.18 \mathrm{IU} / 1$ \\
INR & $1.142 \pm 0.084$ & $1.1 \pm 0.062$ \\
Serum Creatinine & $0.87 \pm 0.33 \mathrm{mg} / \mathrm{dl}$ & $0.91 \pm 0.44 \mathrm{mg} / \mathrm{dl}$ \\
\hline
\end{tabular}

Above table showing the distribution of the liver and renal biochemical parameters in Group A and B. It shows that Bilirubinelevel is $0.55 \mathrm{mg} / \mathrm{dl}$ and $0.58 \mathrm{mg} / \mathrm{dl}$ respectively. ALT level is 34.16 IU/L and 29.16 IU/L. ALP is 79.95 and $88.6 \mathrm{IU} / \mathrm{Lin}$ groupA and $\mathrm{B}$. GGT is $51.23 \mathrm{IU} / \mathrm{L}$ and $49.23 \mathrm{IU} / \mathrm{L}$. INR is 1.14 and 1.1 respectively. 
Creatinine is $0.87 \mathrm{mg} / \mathrm{dl}$ and $0.91 \mathrm{mg} / \mathrm{dl}$ in Group A and group B.

\section{Discussion:}

The search of effective anti-viral treatment against COVID-19 has led us to look into the existing drugs with anti-viral properties which may be effective against this novel CORONA virus. Ivermectin is a wellestablished anti-parasite drug used in both human and livestock animals. In-vitro studies have found profound anti-viral effect of this drug against several RNA viruses5including SARS-CoV-2.21 doxycycline has been is claimed to have antiviral properties by several mechanisms. 22It may also have a role of the antiinflammatory effect of doxycycline in COVID-19 infection.23In this study, 200 patients received the combination of ivermectin (18 mg single dose) and Doxycycline (100 mg twice daily for 5 days). Majority $(78.5 \%)$ were male, mean age was 36 years (range 17 to 74 years).Fever (57.5\%) was the commonest symptom followed by cough (47.5\%), sore throat (8.5\%), dyspnoea $(8.5 \%)$. A significant number of patients $(22 \%)$ were asymptomatic (Non-specific symptoms) in Group-A. On 5 thand 6 thday viral clearance were achieved by $66 \%$ and $83.5 \%$ respectively. ivermectin and doxycycline combination were well tolerated by the patients though some unusual symptoms were seen might have been attributed to the effect of drugs or to rare Covid related symptoms which were anorexia (23.5\%), diarrhoea (12\%), skin rash (10\%) and vomiting (3.5\%). No significant renal or hepatic impairment was found. ivermectin was found to be safe at current dose. 24 In Group-B Fever (66\%) was also the commonest symptom followed by cough $(59 \%)$, sore throat $(6.5 \%)$, dyspnoea $(19 \%)$. Asymptomatic (Non-specific symptoms) patients were only $10 \%$. The effect of hydroxychloroquine (HCQ) with or without azithromycin, on COVID-19 was promising in several studies where HCQ and azithromycin showed earlier viral clearance than placebo. 25 In this study, 200 patients received HCQ \& azithromycin combination. Mean age was 39.4 years (range $20-79$ years) and $94 \%$ were male. All had mild to moderate disease.Viral clearance by RT-PCR of nasal and pharyngeal swab were $77 \%$ at day 11 and $81.5 \%$ at day 12 . No major adverse effect were observed other than minor overlapping symptoms (anorexia $31 \%$, diarrhoea $7 \%$, vomiting $2 \%$, skin rash $1 \%$ ). In this study only mild to moderate COVID19 cases were included. ivermectin and doxycycline combination was associated with earlier viral clearance than HCQ \& azithromycin combination. No severe adverse effect was observed in either group. This is a new study; So far no definite study was found on human being affecting viral clearance of covid-19. This is a observational study and we have choose very low dose of ivermectin keeping consideration of individual safety.The exact dose which will be absolutely beneficial for viral clearance of covid-19 on human being need to be determined in future by further control study.

\section{Limitations}

There are few limitations of the study like a) no severe cases were included in this study, b) effect of drug combination on clinical follow up outcome were not assessed and compared, c) false negative result could not be excluded and d) cardiac effect due to drugs could not be monitored. e) Effective dose of Ivermectin to clear virus not measured.

\section{Conclusion:}

Ivermectin and Doxycycline is a safe combination and found effective in early viral clearance in mild to moderate COVID-19 patients. On the other hand Hydroxychloroquine (HCQ) and Azithromycinewas also found safe but took more time in viral clearance and it itself might putting extra adverse effect on already compromised heart from viral effect. Nevertheles further control study is required to know more about the effects of ivermectin and doxycyclin on covid -19 patient

\section{References:}

1. Shrikrushna et al. 2020. A review on corona virus (covid19). wjpls, 2020, Vol. 6, Issue 4, 109-115

2. Gonzalez Canga, A.,et al., 2008.The pharmacokinetics and interactions of ivermectinin humans-amini review. AAPS J. $10(1), 42-46$

3. Gotz, V.,et al.,2016. Inûuenza A viruses escape from MxA restriction at the expense of eûcient nuclear vRNP import. Sci. Rep. 6, 23138.

4. Lund berg,L.,et al., 2013. Nuclear import and export inhibitors alter capsid protein distribution in mammalian cells and reduce Venezuelan Equine Encephalitis Virus replication. Antivir. Res. 100(3),662-672.

5. Tay ,M. Y.,et al., 2013. Nuclear localization of dengue virus (DENV) 1-4 non-structural protein 5; protection against all 4 DENV serotypes by the inhibitor Ivermectin. Antivir. Res. 99(3),301-306.

6. Wagstaû ,K. M.,et al., 2012. Ivermectin is a speciûc inhibitor of importin alpha/beta- mediated nuclear importable to 
inhibit replication of HIV-1 and dengue virus. Biochem. J. 443(3), 851-856.

7. Wagstaû ,K. M.,et al., 2011. An Alpha Screen (R)-based assay for high-through put screening for speciûc inhibitors of nuclear import. .J. Biomol. Screen 16(2),192-200.

8. Rowland, R .R.,et al., 2005. Intra cellular localization of the severe acute respiratory syndrome corona virus nucleocapsidprotein : absence of nucleolar accumulation during infection and after expression as a recombinant protein in verocells .J. Virol. 79(17),11507-11512.

9. Timani, K.A. ,et al., 2005. Nuclear / nucleolar localization properties of C-terminal nucleocapsid protein of SARS corona virus. Virus Res. 114(1-2),23-34.

10. Wulan, W. N.,et al., 2015. Nucleocytoplasmic transport of nucleocapsid proteins of enveloped RNA viruses. Front. Microbiol. 6,553.

11. Hiscox, J. A., et al., 2001. The corona virus infectious bronchitis virus nucleoprotein localizes to the nucleolus. J. Virol.75(1),506-512.

12. Wurm, T.,et al., 2001. Localization to the nucleolus is a common feature of corona virus nucleoproteins, and the protein may disrupt host cell division. J. Virol.75(19), 9345-9356.

13. Frieman, M., et al., 2007. Severe acute respiratory syndrome corona virus ORF6 antagonizes STAT1 function by sequestering nuclear import factors on the rough endoplasmic reticulum / Golgi membrane. J. Virol. 81(18),9812-9824.

14. Menozzi A, Bertini S, Turin L, Serventi P, Kramer L, Bazzocchi C. Doxycy-cline levels and anti Wolbachia antibodies in sera from dogs experimentallyinfected with Diroûlaria immitis and treated with a combination of ivermectin/doxycycline. Vet Parasitol 2015;209: $281-4$.

15. Guzzo CA, Furtek CI, Porras AG, et al. Safety, tolerability, and pharmacokinetics of escalating high doses of ivermectin in healthy adult subjects. J Clin Pharmacol 2002;42: 1122-33.
16. Zhou D, Dai SM,Tong Q. COVID-19:a recommendation to examine the effect of hydroxychloroquine in preventing infection and progression. J Antimicrobechemother .2020: dkaa 114.

17. DH Tran, R Sugamata, T Hirose, S Suzuki, Y Noguchi, A Sugawara, et al.Azithromycin, a 15-membered macrolide antibiotic, inhibits influenza $\mathrm{A}(\mathrm{H} 1 \mathrm{~N} 1) \mathrm{pdm} 09$ virus infection by interfering with virus internalization process $\mathrm{J}$ Antibiot (Tokyo), 72 (2019), pp. 759-768,

18. M Mauthe, I Orhon, C Rocchi, X Zhou, M Luhr, KJ Hijlkema, et al.Chloroquine inhibits autophagic flux by decreasing autophagosome-lysosome fusionAutophagy, 14 (2018), pp. 1435-1455

19. P.Gautret, J.C.Lagier, P.Parola, etal., Hydroxychloroquine and azithromycinasa treatment of COVID-19: results of an open-labelnon-randomized clinical trial, Int. J. Antimicrob. Agents(2020)105949, https://doi.org/10.1016/ j.ijantimicag. 2020. 105949 [published Online First:2020/ 03/25].

20. Wang W, Xu Y, Gao R, etal . Detection of SARS-CoV-2 in different types of clinical specimens[JAMA.]. JAMA 2020. 10.1001/jama.2020.3786. 32159775

21. Caly L, Druce JD, Catton MG, Jans DA, Wagstaff KM (2020 Apr) The FDA-approved Drug Ivermectin inhibits the replication of SARSCoV-2 in vitro. Antiviral Res. $3: 104787$

22. Zakeri B, Wright GD. Chemical biology of tetracycline antibiotics. Biochem Cell Biol 2008;86(2):124-36.

23. Henehan M, Montuno M, De Benedetto A. Doxycycline as an anti-inflammatory agent: updates in dermatology. J EurAcadDermatolVenereol 2017;31(11):1800-8.

24. Parsippany, NJ: Ivermectin tablets [prescribing information].Edenbridge Pharmaceuticals, LLC; January 2014.

25. Gautret P, Lagier JC, Parola P, Hoang VT, Meddeb L, Mailhe $M$, et al. Hydroxychloroquine and azithromycin as a treatment of COVID-19: results of an open-label nonrandomized clinical trial International Journal of Antimicrobial Agents (2020) (prepublication). 